\title{
State of the Art in Research on Optimum Design, Reliability and Control of Renewable Energy Microgrids
}

\author{
Abubakar Abdulkarim 1,6, Nasir Faruk2, A. O. Oloyede², Lukman A Olawoyin², Segun I. Popoola ${ }^{3}$, A. I. \\ Abdullateef $^{1}$, O. Ibrahim ${ }^{1}$, N.T. Surajudeen-Bakinde ${ }^{1}$, S. M. Abdelkader ${ }^{5}$, John. D. Morrow ${ }^{6}$, Y. A. \\ Adediran $^{1}$, Y. Jibril ${ }^{6}$
}

${ }^{1}$ Department of Electrical and Electronics Engineering, University of Ilorin, Nigeria

${ }^{2}$ Department of Telecommunication Science, University of Ilorin, Nigeria

${ }^{3}$ Department of Electrical and Information Engineering, Covenant University, Ota, Nigeria

${ }^{4}$ Electrical Engineering Department, Mansoura University, Mansoura 35516, Egypt

${ }^{5}$ School of Electronics, Electrical Engineering and Comp Science the Queens University of Belfast, UK

${ }^{6}$ Department of Electrical Engineering, Ahmadu Bello University Zaria, Nigeria

*Corresponding author: aabdulkarim02@qub.ac.uk, abkzarewa@yahoo.com; Tel: +2348035291511

\begin{abstract}
This paper has presented a comprehensive review in the area of microgrid from the design to implementation. The aim is to evaluate the current status, problems and research efforts toward realising functional microgrids in the power system. The expectations about microgrid are many; therefore the study is divided into three main sections. Recent advancements in the wind energy, solar energy and their future prediction are summarised. States of arts in optimum design of renewable energy microgrid are also investigated. In addition, critical literature review in the reliability analysis of microgrids consisting of renewable energy sources is also reported. Control of microgrids consisting renewable energy sources have been presented. Some examples of existing microgrids across the globe are critically reviewed. The work therefore recommends that energy planners and all stakeholders should consider environmental and regional difference in microgrids planning. Finally, future research areas and directions in these areas are highlighted.
\end{abstract}

Keywords: Microgrids, Wind, Solar, Reliability, Control.

Article History: received 24 May 2018; accepted 17 December 2018; published 26 December 2018.

\section{INTRODUCTION}

Statistics of the World Energy Council (WEC) has shown that nearly 1.5 billion people have no access to electricity. These forced nearly three billion people to use wood for their daily energy needs [1]. Further analysis has revealed that a greater percentage of them are from Sub-Saharan Africa, India and South Asia [2]. Most of these people live in rural areas where extending the grid may be challenging. Furthermore, isolated area/loads are still in search of costeffective means of power generation. Future forecasts by the WEC has shown that if all the stakeholders are not committed, there could still be about 880 million people by 2030 and 530 million people by 2050 without electricity, thereby, defeating the Sustainable Development Goals (SDGs).In order to achieve higher penetrations of electricity across the globe, more commitments from various stakeholders are necessary, leading to the declaration of 2014-2024 by the United Nations general assembly as the decade of sustainable energy for all [3]. Moreover, investigations have also revealed that, global energy demand is increasing along with the world population. The majority of people without access to electricity are in rural and isolated areas which are characterised with high rates of poverty, low income, lack of supporting infrastructure and extreme terrain features.
These challenges make extension of electric grid a difficult task.

Ordinarily, the cost of supplying grid-based electricity to these locations, should be less when compared to alternative off-grid options, however, the distances of these remote locations to the nearby transmission and distribution lines are beyond what could be sustained. These therefore, make the cost of grid extensions unattainable and, as such, standalone renewable energy microgrids become viable option. Among these options, wind and solar energy are the most widely proposed renewable energy sources. Thus, there is a need to evaluate the current status, problems and research efforts toward realising functional microgrids in the power system for sustainable development. This paper presents a comprehensive review in the area of microgrid from the design to implementation perspectives. In addition, the recent advancements in the wind energy, solar energy and their future prediction are provided. The states of arts in optimum design of renewable energy microgrid are also investigated. Extensive review in the reliability analysis of microgrids consisting of renewable energy sources is also reported. 


\section{THE GLOBAL OUTLOOK OF RENEWABLE ENERGY SOURCES}

This section provides the recent advancements, deployments in the wind energy, solar energy and their future prediction as they are the most widely proposed renewable energy sources.

\section{1 Solar energy}

The global installed capacity for solar power electricity has seen an exponential growth in the last decade. In 2014, the Photovoltaic (PV) systems increased by $47 \mathrm{GW}$ with a year-on-year growth rate of $24 \%$ as shown in Figure 1 [3]. Germany has sustained her leading role in PV installation over the decade; followed by China, Japan, Italy and United States. These countries have generated around 227 GW of electricity from solar energy at the end of 2015. With addition of $75 \mathrm{GW}$ in the 2016 increasing the global power generating capacity to about $302 \mathrm{GW}$. In 2016, about $75 \mathrm{GW}$ of new installation was added making the global power generating capacity to about $302 \mathrm{GW}$. In the same way, about two-third of the growth is from China recorded $(34.5 \mathrm{GW})$ and USA $(14.5 \mathrm{GW})$ combined together. In the same year, Japan provides $8.6 \mathrm{GW}$ additional. In terms of cumulative installed capacity China maintained the lead $(78.1 \mathrm{GW})$ making about more than one quarter of world total. Japan is second $(42.8 \mathrm{GW})$ followed by Germany (41.3 GW) and USA (40.3 GW) behind Germany as shown in the Figure 1. The actual output of the PV system shows that, solar power generation has witnessed rapid increased in 2016 with about $26.6 \%$ increased.

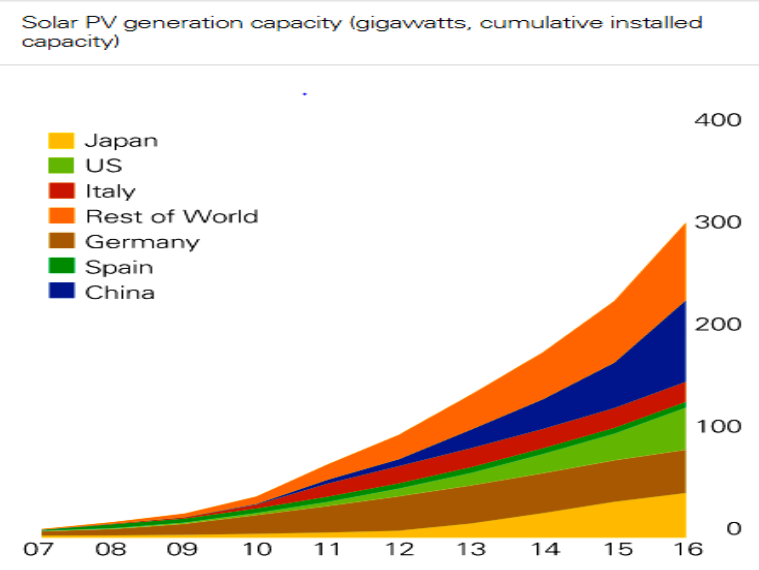

Figure 1. World solar energy [3]

This breakthrough makes it to have a noticeable impact in global power growth, contributing to more than $20 \%$ of the global power growth in 2016. Some of the factors responsible for higher penetration include a decrease in the cost of the solar panels, feed-in-tariffs, investment tax credits, subsidies, renewable energy portfolio, financial facilitation, public investment, net metering, lower lifetime costs and government policies that actually contribute to the business feeling comfortable [4]. It is unfortunate to note that the major installation of solar system has been in regions with less solar energy resources (China and Europe). On the other hand, tropical regions with high solar energy sources such as African and some parts of Middle East remain underutilised. However, the cost of solar system are falling in many countries while, the market of solar system are opening in emerging and developing nations. Recent investments in this area have exceeded those in the conventional power based systems. Figure 2 shows recent trend in solar power investment, this represents a huge investment in solar energy technology. The trend shows that irrespective of the scenario, solar power in the next five years will still be between low and high scenarios. Presently, Asia continent is dominating about $60 \%$ of the market share with the trend to continue for next five years. The same region is expected to absorb about half of the new installation of solar power by 2020 . Critical look at the figure indicates rapid solar power spread across the continent for the period under review. However, the top four countries China, US, India and Japan each is expected to add at least $20 \mathrm{GW}$ by 2020 . Also, in the high scenario; China is the only country that could exceed $100 \mathrm{GW}$ level. This could be achieved with help of optimum supply of installation component and technology to mention just a few. Recent technological advancement has shown that the efficiency for solar cells has reached $46 \%$. In order to take care of environment, there is need for strict and consistent regulations on the entire life cycle of the solar system.

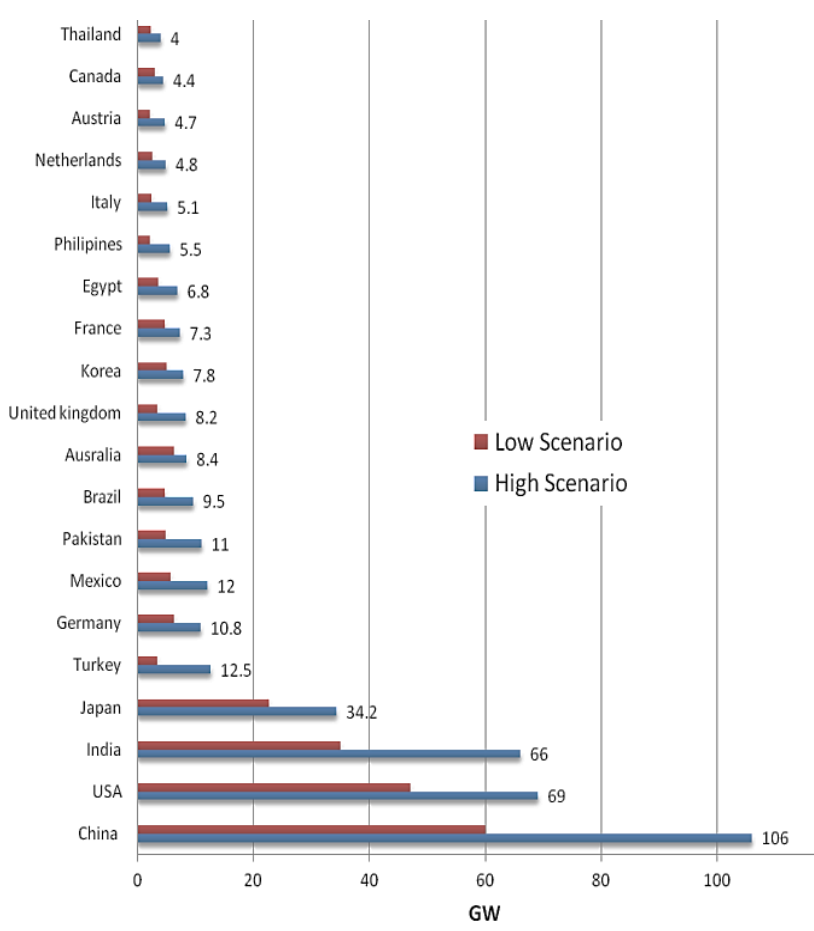

Figure 2. Figure 2. Markets Solar PV additions for High and Low Scenarios 2016-2020 [5]

\subsection{Wind energy}

An increase in wind energy penetration that was equal to about half of global electricity growth was witnessed in 2015 , in fact about $60 \mathrm{GW}$ was installed this year. It has been noted by the World Wind Energy Association (WWEA), the last record set was in 2014, when nearly 50 GW of wind energy was added to the global capacity [8]. Moreover, as depicted in Table 1, there was an increase in the market volume of wind energy by about $40 \%$ in 2014 more than 2013 and significantly larger than 2012 when 44.6 GW was added. A total of $953 \mathrm{MW}$ was added to the wind energy capacity by Africa and Middle East continents. This brings the cumulative installed capacity from these regions up to $3489 \mathrm{MW}$. Latin America and the Caribbean on the other hand saw an increase of $3652 \mathrm{MW}$ with Brazil taking the lead. In Europe, Germany account for about $50 \%$ of the EU wind installation with about 6013 
MW out of 13805 MW wind energy installation. Furthermore, 8598 MW worth of wind energy was added by the US out of $10817 \mathrm{MW}$ supplied from North America. Finally, about $33.9 \mathrm{GW}$ of wind energy was added from Asia region with China generating about $90 \%$ of this value.

After 2014 records, the wind power has surprise the world with another breaking in 2015 recording annual growth of about $22 \%$. The big story behind this record was China by installing $308 \mathrm{GW}$ as against the backdrop in a slowing economy and nearly flat demand. In addition, US, Mexico, Europe, Canada and other new markets emanating from different part of the world. The wind energy market will continue to grow due three main drivers. These includes climate, cratering prices and US market stability. Figure 3 provides the regional scores of wind energy capacity.

Figure 4 shows that for the period under consideration, Asia will continue to dominate the wind energy market. This represents at least $50 \%$ of the global market with China still maintained the lead. In the same way, Brazil will continue to drive the market of Latin America. However, South Africa, Egypt and Morocco in a short time will dominate the market in Africa and Middle East with Kenya and Ethiopia coming stronger. On the other hand, policy stability will determine the growth in Pacific region within the same period.

Table 1: Global Installed Wind energy Capacity (MW) (Data Source: GWEC-2015) [6]

\begin{tabular}{|c|c|c|c|c|c|c|c|c|c|c|c|}
\hline Country & $\begin{array}{c}\text { End of } \\
2014\end{array}$ & $\begin{array}{c}\text { End } \\
\text { of } \\
2015\end{array}$ & $\begin{array}{c}\text { Total } \\
\text { End of } \\
2015\end{array}$ & Country & $\begin{array}{c}\text { End of } \\
2014\end{array}$ & $\begin{array}{c}\text { End } \\
\text { of } \\
2015\end{array}$ & $\begin{array}{c}\text { Total } \\
\text { End of } \\
2015\end{array}$ & Country & $\begin{array}{l}\text { End } \\
\text { of } \\
2014\end{array}$ & $\begin{array}{c}\text { End } \\
\text { of } \\
2015\end{array}$ & $\begin{array}{c}\text { Total } \\
\text { End } \\
\text { of } \\
2015 \\
\end{array}$ \\
\hline \multicolumn{4}{|c|}{ AFRICA \& MIDDLE EAST } & \multicolumn{4}{|c|}{ EUROPE } & \multicolumn{4}{|c|}{ LATIN AMERICA \& CARIBBEAN } \\
\hline South Africa & 570 & 483 & 1,053 & Germany & 39,128 & 6,013 & 44,947 & Brazil & 5,962 & 2,754 & 8,715 \\
\hline Morocco & 787 & - & 787 & Spain & 23,025 & - & 23,025 & Chile & 764 & 169 & 933 \\
\hline Egypt & 610 & 200 & 810 & UK & 12,633 & 975 & 13,603 & Uruguay & 529 & 316 & 845 \\
\hline Tunisia & 245 & - & 245 & France & 9,285 & 1,073 & 10,358 & Argentina & 271 & 8 & 279 \\
\hline Ethiopia & 171 & 153 & 324 & Italy & 8,663 & 295 & 8,958 & Panama & 35 & 235 & 270 \\
\hline Jordan & 2 & 117 & 119 & Sweden & 5,425 & 615 & 6,025 & Costa Rica & 198 & 70 & 268 \\
\hline Other1 & 151 & - & 151 & Poland & 3,834 & 1,266 & 5,100 & Honduras & 126 & 50 & 176 \\
\hline Total & 2,536 & 953 & 3,489 & Portugal & 4,947 & 132 & 5,079 & Peru & 148 & - & 148 \\
\hline \multicolumn{4}{|c|}{ ASIA } & Denmark & 4,881 & 217 & 5,063 & Guatemala & - & 50 & 50 \\
\hline PR China & 114,609 & 30,753 & 145,362 & Turkey & 3,738 & 956 & 4,694 & Caribbean & 250 & - & 250 \\
\hline India & 22,465 & 2,623 & 25,088 & Netherlands & 2,865 & 586 & 3,431 & Others & 285 & - & 285 \\
\hline Japan & 2,794 & 245 & 3,038 & Romania & 2,953 & 23 & 2,976 & Total & 8,568 & 3,652 & 12,220 \\
\hline South Korea & 610 & 225 & 835 & Ireland & 2,262 & 224 & 2,486 & \multicolumn{4}{|c|}{ NORTH AMERICA } \\
\hline Taiwan & 633 & 14 & 647 & Austria & 2,089 & 323 & 2,411 & USA & 65,877 & 8,598 & 74,471 \\
\hline Pakistan & 256 & - & 256 & Belgium & 1,959 & 274 & 2,229 & Canada & 9,699 & 1,506 & 11,205 \\
\hline Thailand & 223 & - & 223 & Rest of Europe & 6,564 & 833 & 7,387 & Mexico & 2,359 & 714 & 3,073 \\
\hline Philippines & 216 & - & 216 & Total Europe & 134,251 & 13,805 & 147,771 & Total & 77,935 & 10,817 & 88,749 \\
\hline Other & 167 & - & 167 & of which EU-28 & 129,060 & 12,800 & 141,578 & & & & \\
\hline Total & 141,973 & 33,859 & 175,831 & & & & & & & & \\
\hline \multicolumn{12}{|c|}{ PACIFIC REGION } \\
\hline Australia & 3,807 & 380 & 4,187 & & & & & & & & \\
\hline New Zealand & 623 & - & 623 & & & & & & & & \\
\hline Pacific Islands & 12 & 0,6 & 13 & & & & & & & & \\
\hline Total & 4,442 & 380,6 & 4,823 & & & & & & & & \\
\hline World Total & 369,705 & 63,467 & 432,883 & & & & & & & & \\
\hline
\end{tabular}


Table 2: More Examples of Microgrids

\begin{tabular}{|c|c|c|c|}
\hline Location & $\begin{array}{l}\text { Technical specification } \\
\end{array}$ & Remark and type of control & Reference \\
\hline Boston Bar-BC Hydro & $\begin{array}{l}\text { Radial microgrid driven by two hydro plants } \\
\text { with peak of } 3 \mathrm{MW}\end{array}$ & $\begin{array}{l}\text { Radial/Controlled by } \\
\text { autonomous controller. }\end{array}$ & [7] \\
\hline $\begin{array}{l}\text { Boralex planned islanding } \\
\text { Hydro Qubec }\end{array}$ & $\begin{array}{l}\text { It facilitates replacement of } 40 \mathrm{~km} \text { feeder } \\
\text { serving } 3000 \text { customers with peak of } 7 \mathrm{MW}\end{array}$ & controlled autonomously & {$[8]$} \\
\hline $\begin{array}{l}\text { The CERTS test bed- } \\
\text { United Sates }\end{array}$ & Mesh type microgrid & $\begin{array}{l}\text { Mesh/Controlled by autonomous } \\
\text { controller. }\end{array}$ & [7] \\
\hline UW microgrid-United State & $\begin{array}{l}\text { Radial microgrid driven by PV and diesel } \\
\text { generator }\end{array}$ & $\begin{array}{l}\text { Radial/controlled autonomously } \\
\text { using active power-frequency } \\
\text { droop and voltage control. }\end{array}$ & [7] \\
\hline $\begin{array}{l}\text { Bronsbergen Holiday Park } \\
\text { microgrid - Netherland: }\end{array}$ & $\begin{array}{l}\text { Mesh type microgrid driven by several PV } \\
\text { DGs with central energy storage. Peak } \\
\text { generation capacity is } 315 \mathrm{~kW}\end{array}$ & Centrally controlled. & \\
\hline $\begin{array}{l}\text { Microgrid of Am Steinweg } \\
\text { in Stutensee - German: }\end{array}$ & $\begin{array}{l}\text { Mesh driven microgrid driven by PV, DGs, } \\
\text { CHP and lead acid battery of } 880 \mathrm{Ah} \text {. }\end{array}$ & $\begin{array}{l}\text { Mesh/Controlled Agent based } \\
\text { control. }\end{array}$ & [9] \\
\hline $\begin{array}{l}\text { CESI RICERCA DER test } \\
\text { microgrid - Italy: }\end{array}$ & $\begin{array}{l}\mathrm{LV} \text { driven by } 14 \mathrm{~kW}, \text { PV DG, } 10 \mathrm{~kW} \text { solar } \\
\text { thermal DG, } 10 \mathrm{~kW} \text { biomass CHP DG, } \\
100 \mathrm{~kW} \text { micro turbine CHP DG and battery } \\
\text { storage }\end{array}$ & Agent based control & {$[10]$} \\
\hline $\begin{array}{l}\text { Kythnos island microgrid - } \\
\text { Greece: }\end{array}$ & $\begin{array}{l}\text { Centrally controlled Radial microgrid driven } \\
\text { by } 12 \mathrm{~kW} \text { PV DG, } 53 \mathrm{kWh} \text { battery bank, and } \\
5 \mathrm{~kW} \text { diesel DG }\end{array}$ & Radial/Centrally controlled & {$[10]$} \\
\hline $\begin{array}{l}\text { Microgrid system at } \\
\text { National Technical } \\
\text { University of } \\
\text { Athens (NTUA) - Greece }\end{array}$ & $\begin{array}{l}\text { Laboratory scale microgrid driven by two } \\
\text { PV generators, one wind turbine, and battery } \\
\text { energy storage }\end{array}$ & Agent based control & {$[11]$} \\
\hline $\begin{array}{l}\text { DeMoTec test microgrid } \\
\text { system - German }\end{array}$ & $\begin{array}{l}\text { Two battery units and two diesel generators } \\
\text { and a wind turbine }\end{array}$ & Agent based control & {$[12]$} \\
\hline $\begin{array}{l}\text { University of Manchester } \\
\text { microgrid/flywheel energy } \\
\text { storage laboratory } \\
\text { prototype - UK: }\end{array}$ & $\begin{array}{l}\text { 20kVA radial laboratory microgrid } \\
\text { prototype driven by a synchronous generator } \\
\text { coupled to an induction motor }\end{array}$ & SCADA controlled & {$[12]$} \\
\hline $\begin{array}{l}\text { Aichi microgrid project - } \\
\text { Central Japan airport city }\end{array}$ & $\begin{array}{l}\text { The system is driven by seven fuel cells } \\
\text { rated } 1.4 \mathrm{MW}, 330 \mathrm{~kW} \text { PV and Nas battery } \\
\text { storage }\end{array}$ & Radial & {$[12]$} \\
\hline $\begin{array}{l}\text { Kyoto eco-energy project } \\
\text { (Kyotango project) - Japan }\end{array}$ & $\begin{array}{l}400 \mathrm{~kW} \text {, Gas turbine, } 350 \mathrm{~kW} \text { of fuel cells, } \\
\text { two PV systems and a } 50 \mathrm{~kW} \text { small wind } \\
\text { turbine }\end{array}$ & Mesh/centrally controlled system & {$[13]$} \\
\hline Hachinohe project - Japan & $\begin{array}{l}5 \mathrm{PV} \text { units } 130 \mathrm{~kW} \text { in all, } 4 \text { wind turbines } \\
20 \mathrm{~kW} \text { in all, and } 3 \text { diesel generators rated at } \\
170 \mathrm{~kW} \text { each. }\end{array}$ & $\begin{array}{l}\text { Radial/centrally controlled } \\
\text { system }\end{array}$ & {$[14]$} \\
\hline $\begin{array}{l}\text { Akagi-Central Research } \\
\text { Institute } \\
\text { of Electric Power Industry } \\
\text { (CRIEPI) - Japan }\end{array}$ & $\begin{array}{l}\text { PV generation derived through three } 100 \mathrm{~kW} \\
\text { inverters and a 200kVA dummy load }\end{array}$ & $\begin{array}{l}\text { A Centrally controlled test } \\
\text { system }\end{array}$ & [7] \\
\hline Sendai project - Japan: & $\begin{array}{l}\text { two } 350 \mathrm{~kW} \text { gas engine generators, one } \\
250 \mathrm{~kW} \text { fuel cell, } 50 \mathrm{~kW} \text { PV and battery } \\
\text { storage system }\end{array}$ & $\begin{array}{l}\text { Radial/centrally controlled } \\
\text { system }\end{array}$ & {$[15]$} \\
\hline $\begin{array}{l}\text { Microgrid testbed in Hefei } \\
\text { University of Technology } \\
\text { (HFUT) - China }\end{array}$ & $\begin{array}{l}\text { PV generators, 3-phase wind generation } \\
\text { simulators, fuel cell, battery bank, ultra } \\
\text { capacitor bank, conventional generators } \\
\text { used to simulate small hydro and fossil } \\
\text { generators. }\end{array}$ & $\begin{array}{l}\text { Mesh network/agent based } \\
\text { controller. }\end{array}$ & {$[14]$} \\
\hline $\begin{array}{l}\text { KERI, Korea microgrid } \\
\text { pilot plant }\end{array}$ & $\begin{array}{l}\text { 120kW microgrid driven by PV, PV and } \\
\text { wind hybrid, two diesel generators, and a } \\
\text { battery storage system. }\end{array}$ & Radial network & {$[16]$} \\
\hline
\end{tabular}




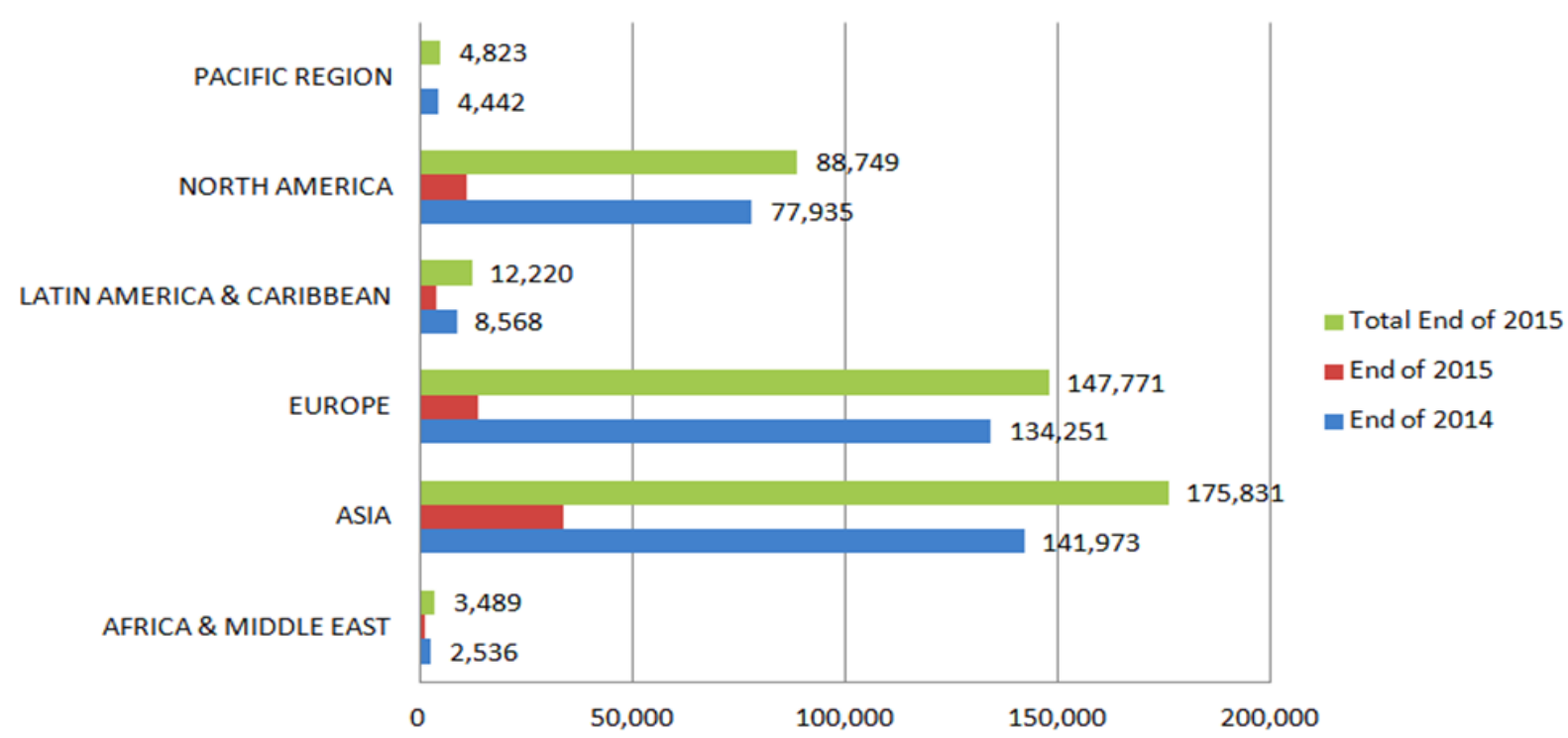

Figure 3. Regional installed wind energy capacity (MW)

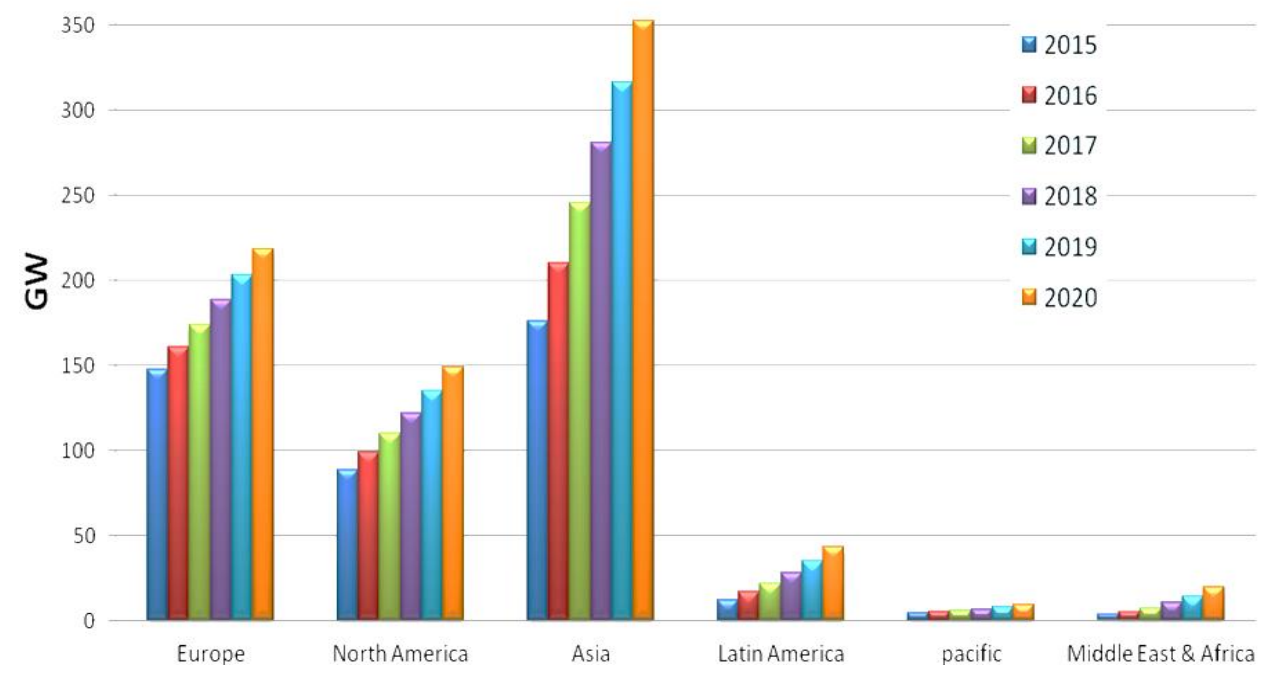

Figure 4: Cumulative market forecast by region 2016-2020 [6].

\section{FUTURE RENEWABLE ENERGY PENETRATION FROM COUNTRIES}

Recent predictions by the International Energy Agency (IEA) have shown that the demand for energy will triple by 2050 [17]. Presently, renewable energy sources contribute to less than $20 \%$ of the world's energy [18]. Future predictions in Figure 5 have shown that the percentage of the installed capacity of non-fossil energy systems will increase to $45 \%$ by 2035 . Also, the World Bank and the IEA have indicated the need to double the global installed energy capacity. This will help to meet the demand from the developing countries in the next 40 years. Many countries are aiming for a higher penetration of renewable energy by 2050 , as a result of this; the global share would be between 15 and $82 \%$ as shown in figure 5 . Denmark generates $39.1 \%$ of its overall electricity from cleaner sources and has a target of $50 \%$ and $100 \%$ by 2020 and 2050 respectively. The United Kingdom aim to meet $15 \%$ of the demand by 2020 , when the Scottish and Northern Ireland intend to achieve $100 \%$ and $40 \%$ by 2020 respectively. The Welsh government indicates the potential of generating twice the amount of electricity it currently uses from renewable energy sources by 2025 . Spain has set a target of $40 \%$ penetration of renewable energy by 2020 while Ireland, which has one of the best wind resources has set a target of a $40 \%$ penetration of renewable energy resources by 2020 . China being the global leader in renewable energy is envisaging that $15 \%$ of its energy needs will be from renewable energy sources by 2050. More renewable energy development in Asian countries can be found in [19] and in Africa in [20].

\section{MICROGRIDS}

A microgrid can be defined as a small electrical distribution system that could connects multiple customers to multiple distributed sources of generation and storage through power electronic devices that provide the necessary interface [22]- [23]. The concept of microgrids is not new as it is dated back to 1882 by Thomas Edison whose company built the first 50 DC power plant. Recently, realities have shown that rising cost of installation, aging infrastructure, natural disaster and lack 
of accessibility to rural areas could hinder continuous power supply. Besides, the global concern on economy, reliability, complexity, demand and control of power system call for a shift form conventional mode of power supply which relies on common/single/national grid. Thus, there is need for smart microgrid system which depends on advance technology that are available in today's world. The development of microgrids is one of the drivers towards a more reliable and quality power to consumers. Depending on the application, a microgrid can be DC, AC or a combination of both (hybrid mode). It can be in single or three phases and sometimes can be connected to a low voltage or medium voltage distribution network [24]. In some cases, it can be operated as a standalone mode. In any of the cases, the system requirements differ in control, stability and reliability, etc. Microgrids systems are usually designed on a small scale with either solar or wind or a combination of the two or more energy sources.

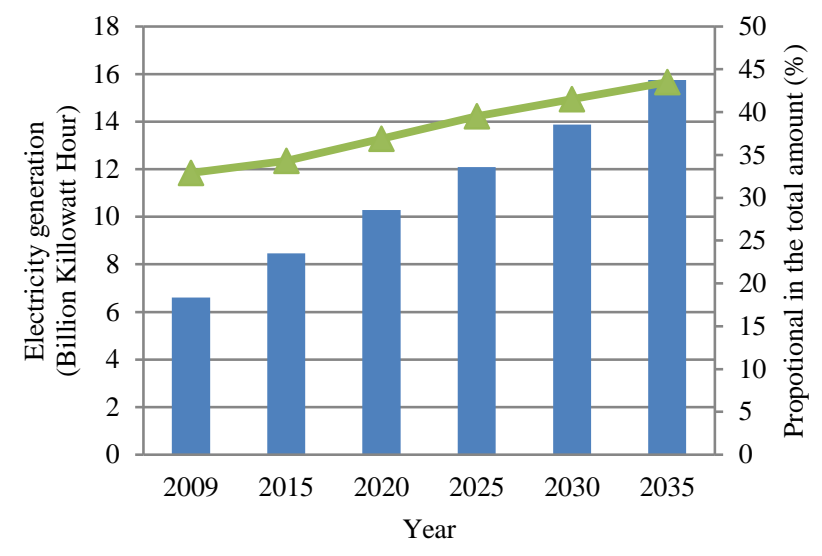

Figure 5. Electricity generation and future development of non-fossil system [21]

The characteristics of a microgrids is the ability of the system to be operated as a small scale power system with ability to generate, distribute and regulate the flow of electrical energy to local customer. Although, it has similar characteristic with backup power system which could temporarily provide power to local customers/loads when there is power outage from the national grid. However, microgrids have benefits and more flexibilities than back up power systems. Some of the benefits include making grid more resilient, counter climate change, adding economic growth, generating making more revenue, saving money, increasing reliability and improving local energy delivery.

Proper sizing of the renewable energy microgrid system depends on many factors. Some of the factors include the amount of renewable energy generation, the weather data, the price of diesel, the load demand and other components [25]. In addition, other issues with the renewable microgrid include economy, control and the reliability of the power supply [26].

\subsection{Research efforts in optimum design of microgrids}

This section reviews some of the recent researches in the area of optimum design of solar, wind and hybrid microgrids across the globe. In [27] the characteristics of lead acid battery as a storage system in the hybrid microgrid were considered, the system is installed for the supply of electricity in the Dongfushan Island in China. An optimization model developed considered only the cost, fuel, environmental and operations costs of the systems. Non dominated sorting genetic algorithm (NSGA II) was used in minimizing cost of generation and minimized the battery life loss. Zhang [28] proposed Dividing the Rectangle (DIRECT) algorithm in the design of $\mathrm{PV} /$ Wind/diesel with battery storage system.

Wang [29] design a hybrid PV-wind generating system by modifying the particle swamp optimization; the algorithm developed simultaneously optimized cost and the reliability of the system. The system designed considered uncertainty in load, wind and solar radiation at different times. Standalone system consisting of solar, wind and battery storage system has been designed using particle swamp optimization in [30].The system design was for the Northern Iran with a life span of 20-year. However, the system may not be optimum when considering a diesel generator and power from the renewable energy sources.

Another algorithm capable of design hybrid energy system includes simulated annealing in [23]. Simulated annealing is of the algorithm that has been used to design hybrid energy system. The algorithm optimized both system operation and unit cost of the system. Other factor that could factors such as uncertainty in the load and load which affect optimum operation were not given due attention. This may make the developed system not be optimum for isolated microgrid especially when uncertainties are incorporated.

Algorithm for the determination of unit sizing and cost analysis for wind, photovoltaic and their hybrid has been proposed in [31]. The algorithm demonstrated the possibility of meeting systems demand and the objective function with the minimum total annual cost of the system. However, the algorithm focused on the economic evaluation of the system without giving attention to the system technical parameters such as battery state of charge, energy balance and component rating etc. Besides, the reliability analysis of the microgrid was not considered; therefore, the developed model may not be the optimum for isolated load.

Procedure capable of maximizing system reliability and minimizing system cost of pv-wind hybrid system using constrained mixed-integer multi objective particle swamp optimization (CMIMOPSO) algorithm was developed in [32]. The inclusion of diesel generator in the design could makes the algorithm not to be optimum for isolated loads. This is because diesel generator may not ensure continuity of supply of electricity especially, when the renewable energy sources and the storage cannot supply the demand. Another algorithm capable of designing a microgrid system is time matching simulation algorithm [33] .However, it has been concluded that, the location of the microgrid may affects the optimum microgrid design [33]. Moreover, the system designed may not be optimum when the diesel generator is introduced in the design.

Recently in [34] model for the optimum design hybrid renewable energy microgrid is proposed, the model minimized system cost while the ratio of cost to reliability minimised. Other effort includes the optimal sizing of a pv/wind/diesel hybrid energy system that can supply a building in Malaysia. The optimal system developed has being confirmed with the result obtained from the HOMER software [35]. [36] Investigated the possibility of using 
wind and solar in the northern part of Jordan. This has actually demonstrated the fact that, microgrid penetration is on the increase around the globe. Study in [37] has carried out an experimental investigation of using solar and wind for power generation in Algeria. The system designed was for freezing and cooling system in the area. The design considered gas emission and renewable energy as the environmental factors while Net Present cost (NPC) and Cost of Energy (COE) were the economic factors. In another development, [38] used multi objective optimization to minimize cost of production, customer outage and emission pollution of a microgrid. More details about the recent hybrid microgrid introduced in the last twelve years and their outcome can be found in [39], [40]. Recently authors in [41] have investigated the effects of battery storage and PV technologies on the optimum design of hybrid renewable energy microgrids; the findings have shown the sensitivity of optimum design to benefit-to-cost ration, payback periods of battery storage and rated powers of wind and solar energy conversion system.

\subsection{Research efforts in reliability studies of microgrids}

Reliability is defined as the probability that a system, product or service operates properly for a specific period of time under operating conditions without failures [34]. Irrespective of the system configuration, the reliability of the system is the most important factor for system planners. However, the success of any design could be attributed to the success of the system when it operates for a longer period.

The relationship between size, location and the reliability of wind turbine has been investigated in [42]. Similar study was carried out by adding storage in the model [43]. In [44]- [45], method of discrete wind speed frame analysis was proposed to analyse the reliability of microgrids. A more advance technique base on multi-state model was proposed in [46] to study the reliability of power system including wind generator. In addition, capacity limitations and transmission line forced outage rates were incorporated in the study [47]. In the same way, Reliability analysis of grid connected microgrids consisting of wind turbine were presented in [48]- [49]. Another investigation was reported on how the rated capacity, charging and discharging behaviour of storage system on the microgrid are related in [50].

Reliability analysis of solar energy microgrid systems in a standalone mode were considered in [51]- [52]. In [51] a multi stage model of a solar conversion model was developed while similar method for the reliability of solar energy microgrids system was proposed in [52]. Other studies carried out on microgrids reliable analysis development includes [53]- [54].Hybrid renewable energy microgrids reliability analysis were carried out in [53]. A multi-state model for the reliability analysis of the WECS and SECS was proposed in [55], a multi-state technique at hierarchical level II was introduced in [54]. Revised capacity outage probability table was used in the reliability study of hybrid microgrid in [56].

Parallel operation of wind and solar energy sources improved the reliability of hybrid energy microgrids in in [57]. Authors in [58] Considered the stochastic nature of

\subsection{Research efforts in control of microgrids}

wind and solar energy using state-sampling taking priority loads into consideration; the results have shown that integration these energy sources increased the reliability of the system. A hybrid technique for the reliability evaluation hybrid renewable energy microgrid consisting wind, solar and battery storage system has been proposed in [57].

Furthermore, Monte Carlo simulation technique as well as effect of load and generation on the reliability of microgrid have been presented and analysed [59]- [60]. Loss of load expectation (LOLE) and loss of load factor (LOLF) are among the reliability indices in which their applications were demonstrated in [59]. A similar analysis was carried out in [61] in which solid oxide fuel cell (SOFC) was added to the microgrid. The relationship between cost and reliability analysis of hybrid PV and wind microgrid have been considered in [62]. A hybrid technique that combined deterministic and probabilistic technique to determine the reliability of hybrid microgrid is proposed and implemented in [63]. Detailed analysis on the effects of implementing PV, WT on the reliability of existing microgrid has been analysed [64]. The relationship between renewable sources of energy variability, periodicity, intermittency and typical distribution demand on the reliability of the microgrid was investigated in [65]. Complexity of storage and variability in the output power of renewable energy sources makes sequential Monte Carlo and minimal path as another viable method to obtain the reliability of grid connected microgrids [60]. A hybrid technique has been proposed to investigate the effects of weather and battery storage on the availability of hybrid renewable energy microgrid [66].

Additionally, minimum path method has been applied to investigate the effects of operation mode and load types on the reliability of renewable energy microgrids [67]. Also, it has been shown that the protection system and operating condition could affect the reliability of microgrid [68]. In [69] minimum path method has been applied to investigate the effects of operation mode and load types on the reliability of renewable energy microgrids In the same way, the extent at which of the repair rate influenced the reliability of microgrid has been analysed [70]. Other efforts include the effects of the renewable energy resources on the reliability of microgrid [71]. Recently, in [72] the reliability of renewable energy microgrid considering the customers' interruptions cost was considered.

In the same vein, studies on microgrid reliability include the development of a load demand model which increased the degree to which microgrids satisfy load efficiently is carried out in [73]. Authors in [74] investigated the impacts of microgrids on distribution system using Failure Mode Effects Analysis (FMEA) technique which shows the ability of microgrid to reduce local load point interruptions and shorten the interruption duration. In addition, the concept of effective capacity is proposed in order to compare the reliability of conventional and renewable energy resources [75]. The analysis showed that either lower FOR or higher average power contributed to better generation reliability. In [76] capacity outrage probability is used to calculate LOLE, EIR, REP and MCPP reliability indices for microgrid.

Most of the literatures on control of microgrid investigated either pv, wind on standalone or both with or without battery. Recent development in [77] proposed coordinated strategy for DC microgrid with variable generation and 
storage. The same authors [78] studies a comprehensive control strategy of a DC voltage control of a four terminal microgrid consisting of variable generation and multiple slack terminals. The system consists of wind, AC, grid, DC load and energy storage system. Investigation of DC voltage control strategy of a DC microgrid as function of different terminals was carried out [71]. Voltage droop power sharing is proposed among the slack terminals in order to achieved power smoothing during normal and grid operations of microgrids.

Some authors [79] have developed a control algorithm for both grids connected and standalone microgrid consisting PV and storage battery only. The algorithm demonstrated the capability of DC power flow between input and output terminal of the microgrid. Multi-loop algorithm capable of inverter control considering battery charge limit and state of charge for PV-storage microgrid has been devised [80]. The choice of control parameters for stability of pv-storage microgrid has been investigated by [81]. [82] Used advanced power control techniques to satisfy the load demand, state of battery, prevent blackout and extend the life of battery of a pv/wind microgrid. This was achieved by the development of active-reactive power control of the microgrid. Similarly another paper [83] considered the use of inverter for the control of standalone microgrid; the developed control strategy was able to cope with variations and disturbance happening in microgrid.

Possibility of splitting the control of a microgrid into top and local level controls has been introduced in [84]. Recently, the control PV/wind/diesel/diesel generator [85] active-reactive power and damp controls have been investigated. It can be seen that the control of microgrid could be either central or autonomous [86].

\section{EXISTING MICROGRIDS AROUND THE GLOBE}

This section reviews some of the existing microgrids in the literatures across the world.

Mesa del Sol mixed commercial-residential development in Albuquerque, New Mexico microgrid. The system comprised of $80 \mathrm{~kW}$ fuel cell, a $240 \mathrm{~kW}$ natural gas-powered generator, a lead-acid battery bank, hot and cold thermal storage, and an adsorption chiller.

Fort Carson microgrid in Colorado Springs USA consists of a $1 \mathrm{MW}$ PV array and three diesel generators with a total power of $3 \mathrm{MW}$, and 5 electric vehicles (EVs) with V2G capability. Some of the problems faced during the implementation of the microgrid project and the demonstration were system ownership and communication related issues.

Santa Rita Jail is the site of one of the best existing microgrid demonstrations in the world today. The system has approximately 1.5 MW of PV, a $1.0 \mathrm{MW}$ molten carbonate fuel cell, back-up diesel generators and $2 \mathrm{MW}$ $4 \mathrm{MWh}$ Lithium Iron battery. The system can function on grid connected or islanded.

The Sendai Microgrid Project, Japan contains two 350 $\mathrm{kW}$ natural gas fired generators, $50 \mathrm{~kW}$ of PV, and battery storage. The developed microgrid network is capable of supplying six varying levels of power quality supplied in different circuits.

Chile's first microgrid project was developed in the University of Chile in a remote Andes Mountains community of 150 residents. The proposed system consists of a $150 \mathrm{~kW}$ diesel generator, $22 \mathrm{~kW}$ tracking solar PV, a $3 \mathrm{~kW}$ wind turbine, a $170 \mathrm{kWh}$ battery, and an energy management system. The system is capable of online set points for generation while minimising operating cost taking renewable energy resources forecast, load, solar tracking and water consumption into consideration. These were achieved with help of energy management system.

Hartley Bay in British Columbia, Canada is a remote coastal village only accessible by air or water. The Gitga' at native community of 170 members operates a remote microgrid there, providing power. Hartley Bay relies on three diesel generators, two of $420 \mathrm{~kW}$ and one of $210 \mathrm{~kW}$ to provide electricity to the 62 residential and 20 commercial buildings.

In the same way the University of New York developed a microgrid that supplies electricity to 22 buildings and heat to 37 buildings across campus. The microgrid network consists of two 5.5 MW gas turbines and a $2.4 \mathrm{MW}$ steam turbine. This has been a great step towards the commitment that the university made to the City of New York to decrease its greenhouse gas emissions by $30 \%$.

Borrego Springs microgrid system has installed capacity $4 \mathrm{MW}$, with the main technologies consisting of two $1.8 \mathrm{MW}$ diesel generators, a large $500 \mathrm{~kW} / 1500 \mathrm{kWh}$ battery at the substation, three $50 \mathrm{kWh}$ batteries, six 4 $\mathrm{kW} / 8 \mathrm{kWh}$ home energy storage units, about $700 \mathrm{~kW}$ of rooftop solar PV, and 125 residential home area network systems.

The Fort Collins Microgrid in Colorado consists of solar PV, CHP, micro turbines, fuel cells, plug-in hybrid electric vehicles, thermal storage, load shedding, and demand side management. The microgrid has a total of $345 \mathrm{~kW}$ of solar $\mathrm{PV}, 700 \mathrm{~kW}$ of combined heat and power, $60 \mathrm{~kW}$ of micro turbines, and $5 \mathrm{~kW}$ of fuel cells. The system has additional diesel-based backup generators totalling $2,720 \mathrm{~kW}$ in capacity, which are mostly used on emergency situation.

Isle of Eigg microgrid project is termed as one of the most successful microgrids project globally. The system is highly successful in integrating multiple renewable of sources into an island-wide community. The system consists of $110 \mathrm{~kW}$ of hydro power generator, two small generators, $24 \mathrm{~kW}$ from four wind turbines and $32 \mathrm{~kW}$ of PV.

Illinois Institute of Technology, USA microgrid project is considered as another breakthrough in implementation of microgrid. The peak load of IIT's campus is around 10 MW. The on campus microgrid consists of two $4 \mathrm{MW}$ combined cycle gas units and a small wind turbine. The University plans to add rooftop PV as well as a $500 \mathrm{kWh}$ battery. Total renewable energy capacity will be about 9 MW. Once this is achieved, the campus will be able to operate as an island most of the time, without importing any power from the grid. The developed microgrid is able to eliminate least three power outages per year resulted in a series of teaching and research disruptions with an estimated cost of $\$ 500,000$ annually and a growing demand for energy.

The UCSD microgrid project supplies electricity, heating, and cooling for 450 hectare campus with a daily population of 45,000 . It consists of two $13.5 \mathrm{MW}$ gas turbines, one $3 \mathrm{MW}$ steam turbine, and a $1.2 \mathrm{MW}$ solarcell installation that together supply $85 \%$ of campus electricity needs, $95 \%$ of its heating, and $95 \%$ of its cooling.

The island of Bornholm is a Danish island situated just south of Sweden that represents roughly $1 \%$ of Denmark's population and electricity load. The supply technologies in the Bornholm Island microgrid consists of 14 diesel generators (34 MW), 1 oil-fired steam turbine (25 MW), 1 
steam turbine running off a mixture of oil, coal, wood chips (37 MW), 35 wind turbines (29 MW), and 2 biogas turbines $(2 \mathrm{MW})$. The site is considered as a field test for European commission to commission and test different microgrid technologies.

Microgrid set up with objective to test centralized and decentralized control strategies for islanding is Kythnos Island. The Island is located in the Aegean Sea and the project was financed fully by the European FP 5 Microgrids program. The system comprised of $10 \mathrm{~kW}$ of $\mathrm{PV}$ at two locations, $53 \mathrm{kWh}$ battery bank, and a $5 \mathrm{~kW}$ diesel generator.

The microgrid project in Mannheim-Wallstadt, Germany, was set up for further microgrid operations and innovations to be tested and operated in city. The system has $4.7 \mathrm{~kW}$ fuel cell, A $3.8 \mathrm{~kW}$ solar PV system, A $1.2 \mathrm{~kW}$ flywheel storage unit and Two CHP units rated at $9 \mathrm{~kW}$ and $5.5 \mathrm{~kW}$ (electrical).

Hangzhou Dianzi University microgrid is Located on the University campus. The microgrid system comprised of PV $(120 \mathrm{~kW})$, a small diesel generator $(120 \mathrm{~kW})$ and fuel cells. The PV system consists of 728 solar panels, occupying an area of $946 \mathrm{~m} 2$. Thus, the microgrid is regarded as the first microgrid to achieved 50\% PV system penetration globally. More details on the existing microgrids can be found in Table 2 .

Critical look at the preceding section shows that regional difference exists in terms of state of art in microgrid. North American countries focused mostly on the reliability of power supply with help of microgrid. On the other hand, European and Asian microgrids are mostly on the utilisation of renewable energy resources. In addition, Asian microgrids are mostly centrally controlled microgrids except China that uses agent based control. However, European microgrids are either centrally controlled or agent based.

\section{FUTURE WORKS AND RESEARCH AREAS}

Microgrid is still one of the futures of power industry; therefore, there are many aspects which are considered as research areas independently. Many areas constituted are hybridized in order to achieve the concept in reality. Some of these concepts include network operation and control, system protection, power electronics, renewable energy, distributed generation, economics issues and communication issues. This is a clear indication that the microgrid will continue to grow in the future. The forgoing review has indicated that while considerable attention has been given in some areas; others are left behind the scheme of things. Table 3 shows some of the future research areas that must be dealt with in order to achieve a realistic penetration and implementation of microgrid.

Table 3: Future research areas for microgrids

\begin{tabular}{|c|l|l|}
\hline $\begin{array}{c}\text { S/ } \\
\text { No }\end{array}$ & \multicolumn{1}{|c|}{ Concept } & \multicolumn{1}{c|}{ Remark } \\
\hline 1 & $\begin{array}{l}\text { Microgrids energy } \\
\text { management }\end{array}$ & $\begin{array}{l}\text { Implementations or } \\
\text { simulations on some of the } \\
\text { proposed models should be } \\
\text { carried out }\end{array}$ \\
\hline
\end{tabular}

\begin{tabular}{|c|c|c|}
\hline 2 & $\begin{array}{l}\text { Protection of } \\
\text { microgrids against } \\
\text { fault current and } \\
\text { design of new } \\
\text { protection scheme }\end{array}$ & $\begin{array}{l}\text { Design of new protection } \\
\text { scheme that will respond to } \\
\text { the needs of microgrid } \\
\text { operation mode and } \\
\text { components. }\end{array}$ \\
\hline 3 & $\begin{array}{l}\text { Incorporation of } \\
\text { high speed } \\
\text { communication } \\
\text { between } \\
\text { components, } \\
\text { operators, } \\
\text { equipment etc }\end{array}$ & $\begin{array}{l}\text { ICT is needed for smart- } \\
\text { metering, and network } \\
\text { controls applied to } \\
\text { microgrids. Example } \\
\text { wireless communication, } \\
\text { power line communications, } \\
\text { bus signaling etc. There is } \\
\text { still difficulty on how to } \\
\text { implements some of the } \\
\text { proposed models. }\end{array}$ \\
\hline 4 & $\begin{array}{l}\text { Policy and } \\
\text { Standards }\end{array}$ & $\begin{array}{l}\text { Standard procedure and } \\
\text { policies are needed in order } \\
\text { to achieve higher penetration } \\
\text { of microgrid across the } \\
\text { globe. }\end{array}$ \\
\hline 5 & Optimization & $\begin{array}{l}\text { Online and offline } \\
\text { optimization systems are } \\
\text { required to enhance energy } \\
\text { price, power losses and } \\
\text { economics }\end{array}$ \\
\hline 6 & AC Microgrids & $\begin{array}{l}\text { Conventional island systems } \\
\text { to support AC loads are } \\
\text { needed in areas such as rural, } \\
\text { remote and islands. }\end{array}$ \\
\hline 7 & DC Microgrids & $\begin{array}{l}\text { Future microgrids and low } \\
\text { voltage distributions are } \\
\text { expected to be DC due to the } \\
\text { new generators storage } \\
\text { photovoltaic, } \\
\text { superconductors, LEDs } \\
\text { electronic equipment and } \\
\text { laptops to mention just a few. }\end{array}$ \\
\hline 8 & Modeling & $\begin{array}{l}\text { There is need for new } \\
\text { modeling techniques due to } \\
\text { complexity of the future } \\
\text { microgrids. This is as a result } \\
\text { of emergence of new } \\
\text { generators, energy storage } \\
\text { systems, loads, power } \\
\text { electronic interfaces, } \\
\text { distribution network's needs, } \\
\text { frequency ranges and time. }\end{array}$ \\
\hline 9 & Energy storage & $\begin{array}{l}\text { New designs of storage are } \\
\text { expected with high energy } \\
\text { and power densities in order } \\
\text { to coordinate inertia less } \\
\text { microgrids. }\end{array}$ \\
\hline
\end{tabular}

\section{CONCLUSION}

Renewable energy microgrid penetration is on the increase due to environmental concern. Unfortunately, the development introduces various opportunity and challenges. This paper has presented a comprehensive review of renewable energy microgrids across the globe. The future energy demands and the renewable energy potential of some selected countries across the globe were presented. Three areas of interest to researchers, educators 
and developers of microgrid are considered. The review comprised of present and future penetrations and market potentials of wind and solar energy resources across the globe, optimum design, reliability, and control studies of wind and solar energy microgrids. Regional and global status of microgrid has been investigated; also existing microgrid across the globe are critically reviewed. The paper has concluded that the utilisation of microgrids depends on the reason of application. Similarly, variations are observed in many areas such as method of control, application, reliability and utilisation of renewable energy power.

\section{REFERENCES}

[1] R. Ullah, R Akikur, and K. Saidur, "Comparative study of stand-alone and hybrid solar energy systems suitable for off-grid electrification: A review," Elsevier, no. 27, pp. 783-752, 2013.

[2] Lu Zhang, G. Barakat, and A. Yassine, "Design and optimal sizing of hybrid PV/wind/diesel system with battery storage by using DIRECT search algorithm," in 15th International, Power Electronics and Motion Control Conference (EPE/PEMC), 2012 , Novi Sad, Serbia, 2012.

[3] R Kilisek, "Global wind and solar installations exceeded "expert growth predictions," http:// breakingenergy.com /, 2015.

[4] G. R. Timilsina, L. kurdgelashvili, and P. A. Narbel, "Review of solar energy merkets, economics and policies," 2011.

[5] O. Schafmer and M. Schmela, "Global market outlook for solar power 2016 - 2020," 2016.

[6] S Sawyer and K. Rave, "Global wind report annual market update," Global Wind Energy Council, 2016.

[7] B Kroposki et al., "look at microgrid technologies and testing projects from around the world," IEEE Power Energy Magazine, pp. 40-53, 2008.

[8] F. Katiraei, C. Abbey, S. Tang, and M. Gauthier, "Planned islanding on rural feeders-utility perspective," in PES general meeting (Panel on Microgrids), 2008, pp. 1-6.

[9] S. Krishnamurthy, TM. Jahns, and R.H. Lasseter, "The operation of diesel gensets in a CERTS microgrid," in IEEE PES general meetingconversion and delivery of electrical energy in the 21 st century, 2008, pp. 1-8.

[10] N.W.A. Lidula and A.D Rajapakse, "Microgrids research: A review of experimental microgrids and test systems," Renewable and Sustainable Energy Reviews, vol. 15, pp. 186-202, 2011.

[11] I Mitra, T Degner, and M. Braun, "Distributed generation and microgrids for small island electrification in developing countries: a review," SESI Journal, vol. 18, no. 1, pp. 6-20, 2008.

[12] M. Barnes et al., "Microgrid laboratory facilities," in IEEE Future Power Systems, International Conference on, Amsterdam, 2005, pp. 1-6.

[13] I Araki, M. Tatsunokuchi, H. Nakahara, and T. Tomita, "Bifacial PV system in Aichi Airport-site demonstrative research plant for new energy power generation.," Solar Energy Materials and Solar Cells, vol. 93, no. (6-7), pp. 911-916, 2009.
[14] S. Morozumi, H. Nakama, and N. Inoue, "Demonstration projects for grid-connection issues in Japan," Elektrotechnik \& Informationstechnik, vol. 125 , no. 12 , pp. 426-31, 2008.

[15] H. Hatta and H. Kobayashi, "A study of centralized voltage control method for distribution system with distributed generation.," in 19th International Conference on Electricity Distribution, Vienna, 2007, pp. 1-4.

[16] N. Keeyoung et al., "Establishment of a pilot plant for KERI microgrid system based on power IT development program in Korea," in Transmission \& Distribution Conference \& Exposition: Asia and Pacific, Seoul, South Korea, 2009.

[17] World Energy Council, "World energy scenarios composing energy futures to 2050," London, 2013.

[18] A. Zervos, "Renewables 2015 global status report," Paris, 2015.

[19] S. Webb, "Renewable energy in the Asian Pacific," New Zealand, 2014.

[20] A. Miketa et al., "Africa 2030: Roadmap for a renewable energy future," Abu Dhabi. , 2015.

[21] H Cai, Enhancement of power system dynamic stability using electric vehicles and distributed generation. Belfast: PhD thesis submitted to the Queens University Belfast., 2013.

[22] J Li, W Wei, and J. Xiang, "A simple sizing algorithm for stand-alone PV/Wind/Battery hybrid microgrids," Energies, vol. 5, pp. 5307-5323, 2012.

[23] M.A. Hassan and M.A. Abido, "Optimal design of autonomous microgrid using particle swarm optimization," IEEE Transactions on Power Electronics, vol. 26, no. 3 , pp. 755- 769 , 2012.

[24] T.S. Ustun and Aladin, Z. Ozonsoy, "Recent developments in microgrid and example cases around the world-A review," Renewable and Sustainable Energy Reviews, vol. 15, no. 8, pp. 4030-4041, 2011

[25] F. Riahy and G. H. Jahanbani, "Optimum design of hybrid renewable energy system," Renewable Energy Trend and application, vol. 11, no. 1, pp. 231250, 2013.

[26] S. Chowdhury, S.P. Chowdhury, and P. Crossley, Microgrid and active distribution networks. London, United Kingdom: IET, 2009.

[27] Bo Zhao, Xuesong Zhang, Jian Chen, Caisheng Wang, and Li Guo, "Operation optimization of standalone microgrids considering lifetime characteristics of battery energy storage system," , IEEE Transactions on Sustainable Energy, vol. 4, no. 4, pp. 934- 943, 2013.

[28] Lu Zhang, G. Barakat, and A. Yassine, "Design and optimal sizing of hybrid PV/wind/diesel system with battery storage by using DIRECT search algorithm," in Power Electronics and Motion Control Conference (EPE/PEMC), Novi Sad, 2012.

[29] Lingfeng Wang and C. Singh, "PSO-based hybrid generating system design incorporating reliability evaluation and generation/load forecasting," in Power Tech, 2007 IEEE, Lausanne, 2007. 
[30] F. Jahanbani and G. H. Riahy, "Optimum design of hybrid renewable energy system," Renewable Energy Trend and application, vol. 11, no. 1, pp. 231250, 2013.

[31] M.H. Nehrir, G. Venkataramanan and V. Gerez W.D. Kellogg, ", " Generation unit sizing and cost analysis for stand-alone wind, photovoltaic, and hybrid/pv systems," ",IEEE Trans. Energy Conversion, vol. 13, no. 1, pp. 70-75, March 1998.

[32] Lingfeng Wang and C. Singh, "Compromise between cost and reliability in optimum design of an autonomous hybrid power system using mixedinteger PSO algorithm," in International Conference on Clean Electrical Power, 2007. ICCEP '07., Capri, 2007.

[33] K. Tanaka and K. Maeda, "Simulation-based design of microgrid system for a resort community," in International Conference on Clean Electrical Power (ICCEP), 2011, Ischia.

[34] A Abdulkarim, S.M. Abdelkader, and D.J. Morrow, "Model for optimum design of standalone hybrid renewable energy microgrids," Journal of Fundamental and Applied Sciences, vol. 9, no. 2, pp. 1074-1101, 2017.

[35] G. Halasa and J.A. Asumadu, "Wind-solar hybrid electrical power production to support national grid: Case study - Jordan," in IEEE 6th International Power Electronics and Motion Control Conference, 2009. IPEMC '09. , Wuhan, 2009.

[36] A. Mohamed and T. Khatib, "Optimal Sizing of a pv/wind/diesel hybrid energy system for Malaysia," in IEEE International Conference onIndustrial Technology (ICIT), 2013 , Cape Town, 2013.

[37] S. Hanini, B. Abbad, N. K. Merzouk and M. Abbas M. Laidi, "Study of a solar PV-wind-battery hybrid power system for a remotely located region in the southern Algerian sahara: case of refrigeration," Journal of Technology Innovations in Renewable Energy, vol. 1, no. 1, pp. 30-38, 2012.

[38] M. Meiqin, J. Meihong, D. Wei, and L. Chang, "Multi-objective economic dispatch model for a microgrid considering reliability," in 2nd IEEE International Symposium on Power Electronics for Distributed Generation Systems (PEDG), 2010 , Hefei, China, 2010.

[39] R.K. Akikur R. Saidur and K.R. Ullah, "Comparative study of stand-alone and hybrid solar energy systems suitable for off-grid electrification: A review," Elsevier, no. 27, pp. 738-752, November, 2013.

[40] S.N. Bhaskara and B.H. Chowdhury, "Microgrids- A review of modeling, control, protection, simulation and future potential," 2012.

[41] A. Abdulkarim et al., "Effects of PV and battery storage technologies on the optimal sizing of renewable energy microgrid," ELEKTRICA Journal of Electrical Engineering, vol. 17, no. 1, pp. 1-8, 2018.

[42] L. Xu and S. Islam, "Wind-diesel-battery hybrid generation system reliability analysis on site and size fctors," in 4th International Conference on Electrical and Computer Engineering, Dhaka, 2006.
[43] F.A. Bhuiyan and A. Yazdani, "Reliability assessment of a wind-power system with integrated energy storage," Renewable Power Generation, IET, vol. 4, no. 3, pp. 211 - 220, 2010.

[44] X. Liu and S. Islam, "Reliability evaluation of a wind-diesel hybrid power system with battery bank using discrete wind speed frame analysis," in Probabilistic Methods Applied to Power Systems, PMAPS. International Conference on, Stockholm, 2006.

[45] L. Xu, S Islam, A.A. Chowdhury, and D.O. Koval, "Reliability evaluation of a wind-diesel-battery hybrid power system," in Industrial and Commercial Power Systems Technical Conference, ICPS. IEEE/IAS, Clearwater Beach, FL, 2008.

[46] W. Liang, P. Jeongje, C. Jaeseok, and A.A El-Keib, "Probabilistic reliability evaluation of power systems including wind turbine generators considering wind speed correlation," Journal of Electrical Engineering \& Technology, vol. 4, no. 4, pp. 485-491, 2009.

[47] C. Jaeseok, P. Jeongje, C. Kyeonghee, O. Taegon, and M. Shahidehpour, "Probabilistic reliability evaluation of composite power systems including wind turbine generators," in Probabilistic Methods Applied to Power Systems (PMAPS), IEEE 11th International Conference on, Singapore, 2010.

[48] Kyeonghee Cho et al., "Probabilistic reliability evaluation of composite power systems including wind turbine generators," Journal of International Council on Electrical Engineering, vol. 1, no. 3, pp. 274-280, 2011.

[49] J. Park et al., "Relibaility evaluation of interconnected power systems including wind turbine generator," International Journal of Innovative Computing, Information and Control, vol. 8, no. 8, pp. 5797-5808, 2012.

[50] Z.Y. Gao and Peng Wang, "Reliability evaluation of power systems with WTGs and energy storage," in IPEC, Conference Proceedings, Singapore, 2010.

[51] P Jeongje et al., "A probabilistic reliability evaluation of a power system including solar/photovoltaic cell generator," in Power \& Energy Society General Meeting,. PES '09. IEEE, Calgary, AB, 2009.

[52] C.I Jaeseok, P. Jeongje, M. Shahidehpour, and R Billinton, "Assessment of $\mathrm{CO} 2$ reduction by renewable energy generators," in Innovative Smart Grid Technologies (ISGT), Gaithersburg, MD, 2010.

[53] Jeongje Park, Kyeonghee Cho, Taegon Oh, Jaeseok Choi, and A.A. El-Keib, "Evaluation of economic impacts of wind turbine and solar cell generators on power system considering $\mathrm{CO} 2$ emission," in Probabilistic Methods Applied to Power Systems (PMAPS), IEEE 11th International Conference , Singapore, 2010.

[54] M. Aien, A. Biglari, and M. Rashidinejad, "Probabilistic reliability evaluation of hybrid windphotovoltaic power systems," in Electrical Engineering (ICEE), 21st Iranian Conference on, Mashhad, 2013. 
[55] A. Ghaedi, A. Abbaspour, M. Fotuhi-Firuzabad, M. Moeini-Aghtaie, and M. Othman, "Reliability evaluation of a composite power system containing wind and solar generation," in Power Engineering and Optimization Conference (PEOCO), IEEE 7th International, Langkawi, 2013.

[56] B. Kekezoglu et al., "Reliability analysis of hybrid energy systems: case study of Davutpasa campus," in EUROCON, IEEE, Zagreb, 2013.

[57] Z. Liu, W.L. Liu1, G. SU, H. Yang, and G. Hu, "Wind-solar micro grid reliability evaluation based on sequential Monte Carlo," in Probabilistic Methods Applied to Power Systems (PMAPS), International Conference on, Beijing, China, 2016, pp. 1-6.

[58] O. A. Ansari, N Safari, and C.Y. Chang, "Reliability assessment of microgrid with renewable generation and prioritized loads," in IEEE Green Energy and Systems Conference (IGSEC), 2016, pp. 1-6.

[59] M.M. Ghahderijani, S.M. Barakati, and S. Tavakoli, "Reliability evaluation of stand-alone hybrid microgrid using sequential Monte Carlo simulation," in Renewable Energy and Distributed Generation (ICREDG), Second Iranian Conference on, Tehran, 2012.

[60] Angel A. R., K.S. Tapan, and M. Mehdi, "Reliability evaluation with wind turbines and photovoltaic panels," in IEEE PES Transmission \& Distribution Conference and Exposition - Latin America (PES T\&D-LA), Medellin, Colombia, 2014, pp. 1-5.

[61] M.M. Ghahderijani, S.M. Barakati, and S. Tavakoli, "Reliability evaluation of stand-alone hybrid microgrid using sequential Monte Carlo simulation," in Renewable Energy and Distributed Generation (ICREDG), Second Iranian Conference on, Tehran, 2012.

[62] M. M Ghahderijani, S. M. Barakati, and A. Jamshidi, "Application of stochastic simulation method in reliability assessment of a PV-wind-diesel-SOFC hybrid microgrid," IACSIT International Journal of Engineering and Technology, vol. 4, no. 5, pp. 586589, 2012.

[63] R. Karki and R. Billinton, "Reliability/cost implications of PV and wind energy utilization in small isolated power systems," Energy Conversion, IEEE Transactions on, vol. 16, no. 4, pp. 368-373, 2001.

[64] L.N. Kishore and E. Fernandez, "Reliability wellbeing assessment of PV-wind hybrid system using Monte Carlo simulation," in Emerging Trends in Electrical and Computer Technology (ICETECT), International Conference on, Tamil Nadu, 2011.

[65] A.A. Alkuhayli, S. Raghavan, and B.H. Chowdhury, "Reliability evaluation of distribution systems containing renewable distributed generations," in North American Power Symposium (NAPS), Champaign, IL, 2012.

[66] A. Abdulkarim et al., "Effect of weather and the hybrid energy storage on the availability of standalone microgrids," International Journal of Renewable Energy Research, vol. 6, no. 1, pp. 189198, 2016.
[67] L. Gengfeng, Zhaohong B., Bowen H., and Xifan W., "Reliability evaluation of distribution systems including micro-grids considering demand response and energy storage," in 47th International Universities Power Engineering Conference (UPEC), London, UK, 2012, pp. 1-6.

[68] X. Xu, J. Mitra, T. Wang, and L. Mu, "Evaluation of operational reliability of a microgrid using a shortterm outage model," Power Systems, IEEE Transactions on, pp. 1-10, 2014.

[69] Huang Wei, He Zijun, Feng Li, Tian Hongliang, and Zhang Li, "Reliability evaluation of microgrid with PV-wind hybrid system," in Electric Utility Deregulation and Restructuring and Power Technologies (DRPT), 4th International Conference on, Weihai, Shandong, 2011.

[70] M. Theristis and I.A. Papazoglou, "Markovian reliability analysis of standalone photovoltaic systems incorporating repairs," Photovoltaics, IEEE Journal of, vol. 4, no. 1, pp. 414-422, 2014.

[71] S. Kennedy, "Reliability evaluation of islanded microgrids with stochastic distributed generation," in Power \& Energy Society General Meeting. PES '09. IEEE, Calgary, AB, 2009.

[72] I. Bae and Jin-O Kim, "Reliability evaluation of customers in a microgrid," Power Systems, IEEE Transactions on, vol. 23, no. 3, pp. 1416- 1422, 2008.

[73] Z. Ping et al., "Reliability evaluation of gridconnected micro-grid considering demand response," in Published in: Probabilistic Methods Applied to Power Systems (PMAPS), International Conference on, Beijing, China, 2016, pp. 1-5.

[74] W. Chengming, Jie L., and Yabin W., "The impacts of microgrid on the reliability of distribution system," in 2nd International Conference on Consumer Electronics, Communications and Networks (CECNet), Yichang, China, 2012, pp. 1423-1426.

[75] W. Chengming, Jie L., and W. Yabin, "An effective capacity for generation reliability evaluation of renewable power plant," in IEEE 8th International Power Engineering and Optimization Conference (PEOCO2014), Yichang, 2014, pp. 418-422.

[76] N. Nima and N. Sajad, "Reliability evaluation in multi-microgrids under probabilistic optimum operation using heuristic algorithm," in Smart Grid Conference (SGC 2015), Tehran, 2015, pp. 92-98.

[77] $\mathrm{L} \mathrm{Xu}$ and D. Chen, "Control and operation of a DC microgrid with variable generation and energy storage," IEEE Transactions on Power Delivery, vol. 26, no. 4, pp. 2513- 2522, 2011.

[78] D. Chen and L. Xu, "Autonomous DC voltage control of a DC microgrid with multiple slack terminals," IEEE Transactions on Power Systems, vol. 27, no. 4, pp. 1897- 1905, 2012.

[79] L. Arnedo and V. Blasko, and S. Park S. Dwari, "80 $\mathrm{kW}$ hybrid solar inverter for standalone and grid connected applications," in Twenty-Seventh Annual IEEE on Applied Power Electronics Conference and Exposition (APEC), 2012 , Orlando, FL, 2012. 
[80] H. Mahmood, D. Michaelson, and Jin Jiang, "Control strategy for a standalone PV/battery hybrid system," in Annual Conference on IEEE Industrial Electronics Society IECON 2012 - 38th, Montreal, QC, 2012.

[81] X. Xiong, C.K. Tse, and X. Ruan, "Bifurcation analysis of standalone photovoltaic battery hybrid power system,", IEEE Transactions on Circuits and Systems I: Regular Papers, vol. 60, no. 5, pp. 13541365, 2013.

[82] and K. Duraiswamy K. Jaiganesh, "Dump power control techniques for standalone hybrid wind/solar power generation control," in International Conference on Emerging Trends in Science, Engineering and Technology (INCOSET), 2012, Tiruchirappalli, Tamilnadu, India, 2012.

[83] M. Abdel-Salam et al., "Steady-state modeling and control of a microgrid supplying irrigation load in
Toshka Area," in Annual Conference on IEEE Industrial Electronics Society IECON 2012 - 38th , Montreal, QC, 2012.

[84] M. Negnevitsky, M.E. Haque and A. Gargoom. A.M.OHaruni, "A novel operation and control strategy for a standalone hybrid renewable power system," Sustainable Energy, IEEE Transactions on, vol. 4, no. 2, pp. 402- 413, 2013.

[85] T. Hirose and H. Matsuo, "Standalone hybrid windsolar power generation system applying dump power control without dump load," Industrial Electronics, IEEE Transactions on, vol. 59, no. 2, pp. 988- 997, 2012.

[86] S.P. Chowdhury and P. Crossley S. Chowdhury, S. Chowdhury, S.Microgrid and active distribution networks. London, United Kingdom: IET, 2009. 